\title{
ENGLAND'S WAR AGAINST THE SOUTH AFRICAN REPUBLICS PART II
}

\section{bY COLONEL ROMEIKO-GURKO Translated from Russian and Introduction by Mrs E. Foxcroft*}

\section{Moving into the Second Phase of the Campaign}

The lifting of the siege of Ladysmith and the occupation of Bloemfontein marked the ending of the first phase of the campaign, which lasted exactly five months, during which the Allies blockaded three towns, - in one of which, moreover, the garrison was much more numerous than the besiegers - in the hope of forcing them to surrender. At the same time they tried to hold up the advancing English columns which were moving to their rescue. Besides, holding up the advance, the Allies counted on gaining time, during which the blockaded towns would be forced to surrender, rather than on preventing the enemy from invading the republics. Doing so, and in spite of the English superiority of numbers, they wished while moving as little as possible, and not shifting their camps to keep pace with the movements of English columns, to bar all probable ways of approach to them. As an unavoidable result of this they were obliged to hold positions far away from each other and not very well defended. They did not use reserves but applied the cordon system. But the final failures proved to the Allies the utter uselessness of this system. During the Krygsraad session of March 17 th in Kroonstad, while the allied troops serving in the Orange Free State were home on leave this opinion was expressed by President Steyn and it was supported by all the most outstanding military commanders. Simultaneously a new system of resisting the invading enemy was proposed. This consisted in an increase of activity carried out by small mobile detachments, mainly in the flanks and the rear of the enemy. But in order to put the new system to the test of practice it was essential that its expedience should be recognised not only by the commanders but by the rank and file as well. These were as a rule very much inclined to open discussions and criticism of the orders issued by their superiors. The recent failures would only provide new material to strengthen this tendency. The other condition which would make people be prepared to experiment with a new, more vigorous course of action - is confidence in one's leaders. At that point of the campaign such confidence was already bestowed upon the Generals, Botha, De la Rey and partially, De Wet, who not yet had the opportunity to demonstrate his military talents fully. The first among them, having been appointed by general Joubert as the Commander in Chief of all the forces gathered on the line Dundee-Glencoe, had, after the retreat from Ladysmith, tried on two occasions to persuade the commanders under him, to undertake an offensive movement against General Buller's troops. But having met with an unsympathetic attitude among them, had been forced to give up his intentions of an active conduct of the war on the Natal theatre.

General De la Rey, set himself somewhat apart from active participation in events - although, he, perhaps more than any other general from the Transvaal, realized clearly how to apply the new system of warfare in practice. He was offended because he had not been appointed either acting commander in chief, nor chief commander of the forces gradually collecting at Kroonstad, and which consisted mainly of Free Staters, after the death of General Joubert. Therefore when the government decided to finish in one way or another with the siege of Mafeking, which was making no headway, yet was responsible for the diversion of some 2500 men and some guns away from the main theatre, it offered General De la Rey to assume the command over the besieging corps, which ran the risk of being moved away if help reached the besieged garrison from outside. General De la Rey assumed the command at the beginning of May.

As for De Wet, as soon as he had been joined by his men, he started active warfare. Having let the other commanders remain in the operational direction Bloemfontein-Pretoria, in order to meet the advancing English columns, he decided to go round the left flank of the general disposition of the English forces in order to harass their communication line leading South from Bloemfontein. Realizing perfectly well, that one could not all of a sudden and in a radical manner 
change the Boers opinion on ways of waging war to begin with he applied a course of action in which his men while advancing strategically could still only defend themselves tactically. The very first encounter with the enemy proved a brilliant success for him. He found out from local inhabitants about the whereabouts of an isolated English column of medium size, accompanying a large baggage train, which was moving in the direction of Bloemfontein. He roused his men immediately and marching by night moved from Brandfort to Sannaspos. Approaching the English camp at dawn, he disposed his men in such a way that moving in any direction the column would be forced to attack him. The whole baggage train, seven guns and 400 prisoners of war, were the trophies of the day on which a portion of his forces pretended that they were about to attack, and the other one, remaining hidden awaited the approach of the baggage train and its convoy. Having sent all the trophies to the rear, De Wet continued his raid, intending to finally cut the English communication line. But while on the way he was informed about the isolated position of an English detachment at Wepener, which was composed of mounted infantry about 1500 strong. Counting on repeating the manoeuvre, which had succeeded so well at Sannaspos he changed his direction and moved towards Wepener. But the English detachment, warned in time about De Wet's move, took up a strong defensive position, in a spot where there were considerable supplies of flour. Since his surprise attack did not come off, De Wet should have gone on with the execution of his primary plan, without paying further attention to the English detachment. But the hope of forcing the English to surrender, chained De Wet to Wepener, which he besieged according to all the correct rules. Foreseeing that help would be sent for sure to the besieged from Bloemfontein, he got his brother Piet de Wet to join him with his 3000 men and placed him as a screen at De Wetspoort. In a word, the same thing was repeated as had happened at Ladysmith and at Kimberley, with exactly the same results. Piet de Wet's detachment was unable to stop the enemy, far superior numerically, who was hurrying from all sides to relieve the English at Wepener. After this Christian de Wet could do nothing else but lift the siege. But the pointless fire against the English at Wepener, exhausted his ammunition and cartridge supply to such an extent that he did not take the risk of continuing his interrupted journey South in order to fulfil his original plan of attack on the communication lines, but took the shortest route to the North to join up with the camps pitched at Brandfort, awaiting a new offensive of Lord Robert's forces.

Such was the end of De Wet's first raid on a large scale, well conceived, brilliantly started and which failed through his own fault. However this lesson did not happen in vain and he never again repeated this mistake. He understood that all his actions must be based on the development of extreme mobility instead of lying in wait of small besieged enemy detachments.

During this time, other military commanders who had pitched their camps in a big bow from Thabanchu to the North west, through Brandfort and for some ten miles beyond it to the west, were waiting for the English to leave Bloemfontein and hoped to disturb and harass them on the march. The first Boer actions were successful. This was while the English sent out small reconnoitring columns consisting of mounted infantry with 2 or 3 mounted batteries. The Boers managed not only to stop their progress but even to push them back killing and wounding some and taking some prisoner. But when the main forces of Roberts were moved in the Northerly direction, 4000 Boers, with a few guns were no longer able to stop the advance of the enemy ten times his own number. All attempts to stop the advance of the English columns on the march by a few hidden snipers resulted in a more or less prolonged firing of the English artillery. As the Boers had nothing to retaliate with they had to mount their horses and slowly move north. They even tried once or twice to revert to their old tactics i.e. to occupy strong defensive positions on the banks of a river, but even then the upshot of it all was nothing but more English artillery fire and the threat that the English cavalry might outflank their positions. So after a while they would move their camps to advance further inland. This complete absence of tenacity in defence and the insignificant show of active resistance led the English to suppose that the Boer resistance was at an end and that both the republics were ready for unconditional surrender.

\section{The Gold Mines}

There was only one question, which remained unanswered by the English, which although it had no direct bearing on the conduct of military operations - yet was of paramount importance to them - this was: in what condition would the Boers leave the Johannesburg gold mines? This question also worried everyone in Pretoria and not only persons in important official positions, 
but also many of the well-to-do burghers. The lower classes of the local population, knowing full well that the Johannesburg gold mines were the primary and the most important cause of the Anglo-Transvaal conflict, which culminated in the invasion of a foreign army, quite naturally had a feeling of hatred for these mines. As for those who received no direct or indirect benefit from them, they wished to see them obliterated out of a feeling of vengeance. But the men in power, quite independent of the fact that the majority of them were materially involved in the Johannesburg shareholders, saw in them the only means of paying future expenses and debts incurred during the war, even should their settlement fall on the victors in the eventuality of an unsuccessful end of the war. The government of Pretoria realised that should the mines be damaged, the English would, if only out of vengeance, levy still heavier taxes and contributions on the local country inhabitants. Besides the damage caused by the destruction of the mines would have been borne more by the small shareholders rather than by important capitalists. Moreover the latter, buying up the depreciated shares at the stock exchange, would have in time, with the resumption of work, returned with large interest what they had lost at the expense of the small capitalists. All these considerations prevailed after lively debates in the Executive Assembly, over the desire to act vindictively towards the owners of the mines. Therefore, far from being destroyed, the mining installations were protected by the authorities from all attempts by private persons to blow them up or burn them, on their own initiative.

\section{Surrender is considered}

Simultaneously with that, another question of paramount importance was outstanding in Pretoria. Should Pretoria be used as a fortress and provided with a suitable garrison, be defended to the last extremity? In such a case the government was asked to remain in on the spot, or having repulsed the English for the last time on positions commanding the approaches of the city, in case of failure, to move away and to surrender the fortress-city without a fight. Naturally it was not easy to resign oneself to the thought that one would draw no benefit whatsoever from the enormous expenditure incurred in building forts around the capital. There was also a feeling of fear at the moral effect, made on the population the surrender without a fight and the departure of the government. The President and the persons in his immediate entourage could not reconcile themselves for some time to the thought of not defending the capital. For a long time they would not admit that it would be foolish to lock up and immobilise and sooner or later come to surrender more than half of their armed forces and that those same forces could inflict far greater damage on the enemy in the open field. Some foreigners were approached for a solution to this problem. Meanwhile time passed and the enemy was approaching fast. It was imperative to issue orders either for supplying Pretoria with every thing needed for a prolonged blockade, or to evacuate all the food and ammunition supplies into regions, which could be used for the continuation of the campaign. The President and some of the men close to him had not yet quite realised that they must give up the thought of carrying out large operations, and of the possibility, of stopping a further English advance by means of a tenacious defence of local obstacles barring the way. Among other things, they place great hopes on the defence of the Vaal River, assuming that the burghers would make a big show of resistance to prevent the enemy from entering their own territory - the Transvaal. But the greater were their hopes at the successful defence of this natural obstacle on the way of the enemy toward Pretoria, the greater was the impact of the shocking news that the crossing of the river had not cost the enemy a single man. It is therefore easy to understand the great feeling of depression which spread over the assembly gathered together to discuss further moves. It is understandable why, when some voices were raised proclaiming the necessity to end the strife, as it was now apparent that the burghers did not wish to defend their land, and that no one raised any objections. It was proposed therefore to notify England that the Transvaal, having used up its resources in the struggle with the enemy would be prepared to surrender but under 'protest' i.e. as if appealing to higher justice and protesting against the act of violence committed over it.

President Steyn, notified of this while he was with De Wet's detachment in the North East of the Orange Free State, came to Pretoria immediately and during the session of the Executive Assembly, on behalf of himself and the chief commander of the Orange Free State protested vehemently against such a decision. He quite justly considered this decision not only premature as he sincerely believed that all was not lost but also saw in it a crying injustice in relation to the Orange Free State, which had only been drawn into the conflict out of a feeling of brotherly solidarity with the 'suster republiek' the Transvaal, and now was half in ruins whereas the Transvaal 
was only just seeing the enemy on its territory. Having expounded a future plan of action, which was strictly adhered to from then on by General De Wet, he persuaded the assembly to forget their former decision, and believing in the righteousness of their cause to continue the struggle, hoping for a happy issue. This decision was taken during the last days of May, and only subsequently did the hurried evacuation of ammunition begin from Pretoria along the Eastern railroad to Middelburg.

One other problem still remained; outstanding what to do with food stores. It was feared that if all reserves should be removed the local population might have to face starvation. Therefore it was decided to allow each person to take what they could from government provision shops. But seeing that this turned into pillage, in which the natives participated as well as the white inhabitants, and that a good half of the products was being spoiled and destroyed through carelessness and haste, it was decided to have police guards in the shops and thus to stop further plunder.

It must be stated that the solicitude for the local inhabitants, i.e. the burghers families both in the cities as well as on their farms should not suffer any unnecessary privations, was one of the chief reasons why guerilla warfare found so little support among the majority of the burghers on the territory of the republics. Even military commanders, retreating with their commandos before the advancing enemy, knowing well that all the provisions left behind on the farms would inevitably fall into English hands, still did not dare to issue the order to destroy them. This came partly from a feeling of inherent respect for other peoples' property, at any rate as long as the proprietor remained on the spot. Some even imagined naively that the invading enemy would also respect other peoples' possessions, especially if the owner declared himself to be such, and that even if anything was taken, that it would all be paid for.

But, not withstanding the decision not to defend Pretoria, General Botha, still intended to try and stop the further advance of the main English forces, which had crossed the Vaal river without encountering any resistance. With this in view he disposed his troops, or rather what was left of them, on the heights along the left banks of the Klip river, south of Johannesburg. The commands protecting the lower basin of the Vaal river and the troops, which had been engaged in the siege of
Mafeking, which had ended unsuccessfully, all collected there as well. The order to storm Mafeking had been issued in Pretoria. But seeing that the number of men still remaining in the camps, was constantly dwindling with the approach of the enemy to the border of the Transvaal, it was considered impossible to maintain 2000 men around Mafeking, whose surrender was not expected in the immediate future. On the other hand it was thought inadvisable to lift the siege without first trying to take the town by open force. So the commander of the besieging forces was ordered to prepare for a storming. General de la Rey who was not in sympathy with this plan, was sent to take charge of the operation. One must admit that of all the towns, besieged by the Boers to this stage of the campaign, they undertook to take by force, the only one, whose, garrison thanks to the great activity displayed by its commander BadenPowell, had preserved the best morale and was therefore in a position to offer the most spirited resistance to the attackers. Volunteers were called for and their small number, even before the start, doomed the whole operation to failure. The position was worsened by an almost total absence of guns on the Boer side. As the attempt to take the town by open force failed, an order was given to retreat towards Johannesburg, in order to strengthen the concentration of troops to the South. The detachments, which had been besieging Mafeking, arrived under de la Rey's command and occupied positions to the South West of Johannesburg, thus forming the right flank of the general defence position. But in spite of a few isolated successes, during this defence, the Transvalers were forced to move to the North of Johannesburg, after having yielded the railway junction of Elandsfontein to the English.

\section{The march against Pretoria}

General Botha surmised that, having occupied Johannesburg, the English forces would move on to Pretoria. At that time there were still very considerable stores of provisions and ammunitions there, which were intended to be sent by railway to the East. In order to gain time, he deemed it essential to organise the defence of a strong natural position to the South of the capital, next to Irene station. The troops stationed on the Witwatersrand heights as well as those along the Klip Riversberg were ordered to collect there. But the detachments, having once begun the retreat, would not stop according to the orders received, south of Pretoria, but continued to retreat as far as the city itself and beyond it to the North. Thus, 
beginning on May 31st, the approach to Pretoria was barred only by a few hundred men of the Johannesburg police and an equal number of burghers, with ten to twelve guns in all. But if there were still these remnants defending the city on that side, there was not a single armed burgher left to the East, which needed protection to ensure a safe movement of trains along the East railroad. The English forces, having reached Johannesburg and having occupied it without any great efforts, were so weary from the preceeding marches, that they needed a few days rest, and were unable to move on immediately to occupy Pretoria. It still appears incomprehensible that not even a small mounted detachment was sent to blow up the railway line or the bridge on the line Pretoria-Komatipoort, which was being used extensively to move supplies. Meanwhile this gave the Boers the opportunity to send the last trains out of Pretoria, after the English shells began to fall on the outskirts of the town. A timely destruction i.e. immediately after the Vaal crossing, of at least one unimportant railway installation on this line, would have deprived the Transvaal government of the possibility of removing more than half, already not very abundant ammunition stores, in the direction of Middelburg, where it was intended to form a resistance centre, in the hope that the burghers, who had gone to their farms, would rejoin in time. The destruction of the line Pretoria-Komatipoort would have forced the government to send all trains to Pietersburg - that is North and this had never been part of its plan.

Lord Roberts could have achieved, equal, if not better results, if he had given directions to General Buller to put an end to his useless stay near liberated Ladysmith and to move his forces North in order to cut that very same Eastern railway line in the vicinity of Machadadorp. Such a new and unexpected blow, would have - if not forced the Transvaal Government to reconsider its decision to stop the resistance, at least forced it to move out of touch with Delagoa Bay and North, breaking all contact with the outside world. To abandon most of its ammunition, which was loaded into railway carriages scattered all along the line, as there was a great shortage of means of transport by rail. Buller would not have encountered any serious opposition in his advance North at the beginning of June, any more than two months later, although during this period the Boer forces augmented their forces and their morale improved somewhat owing to a few scattered victories. There was no cause for Lord Roberts to anticipate any serious resistance on the way. There was rather every indication for him to believe and openly declare - in view not so much of the fact that the gold mines and the administrative centre of the government had been occupied, but rather on account of the insignificant resistance which his forces had encountered on their way between the capital of the Orange Free State and the capital of the Transvaal - that the war was now at an end. The Commander in Chief of the English armies had reason to surmise that since during the preceeding 8 months there had been no guerilla warfare to speak of, there would be none in the future. This opinion was backed by the fact that General de Wet had displayed no activity and had lain low in the Eastern part of the Orange Free State, which can be explained both by the exhaustion of his ammunition and by the poor condition of his horses, which require some rest. Lord Roberts was not aware of that inner change, that moral transformation, which was slowly taking place not only in the minds of the commander and government executives, but also in those of ordinary burghers. The English did not understand that this period of relative passivity and of almost complete ebbing away of vitality in the Boers, had not been in vain and that they had convinced themselves by their bitter experience now, that it was not by defending craggy heights or unimportant mountain streams that they could hold up the enemy advance, he could only be stopped by constant harassing fatigue and if possible, by being deprived of provisions. But even in open battles, both in defence and attack by the end of this period and the beginning of the next, the Boers achieved certain successes. Their military activity and tenacity in defence during Lord Robert's advance towards Bloemfontein and later to the Vaal, were considerably weaker, than during the days of the fights for supremacy of the mountain heights East of Pretoria on the 9th, 10th and 11 th of June.

\section{Effect of the war on the English}

If the Boers did retreat before the numerically superior enemy, at least it cost the English some efforts and considerable loss, in spite of the fact that this was the most critical period of the war for the allies in terms of numerical strength, for after the evacuation of Pretoria the majority of the Burghers had gone to their homes, and some of them had even moved away into the wooded districts of the Northern and North Eastern Transvaal, taking their families and their herds with them. Some had cleared out of the burgher camps because they considered the struggle at 
an end and its continuation pointless; others were very weary of the prolonged camp life and longed for a rest. Many left because they wanted to save their families and possessions from the possibility of these falling into English hands. For this reason they sent them with all their cattle to the Portuguese border, that is to their usual winter pastures. Some of the horses had become so thin and weak that they needed prolonged rest and better fodder, which at this point could only be found in the valleys of the Eastern regions. As for those who had lost their horses altogether they did not consider themselves able to continue the fight. The great weariness of the horses in the Allied ranks, thanks to great exertions and poor fodder consisting almost exclusively of dried grass, could not but effect the fighting quality of the Boers and forced them to give up the development of any guerilla warfare until the first spring rains, which precipitate the growth of nourishing pastures, thanks to which the horses would quickly recover. This accounts for the phenomenon of lack of resistance by the Boers against the English after the occupation of Pretoria, - during the winter months.

After the evacuation of Pretoria the government of the Transvaal dispatched agents to districts not yet occupied by the enemy in order to notify the population that everyone must proceed to join the Commandant General East of Pretoria. So it came to pass that several thousand men assembled near the railway line already to continue the struggle. It was decided in the Military Council that General Commandant Botha would remain along the railway line with the burghers of the occupied territories (Pretoria, Krugersdorp, Johannesburg) as well as with the Eastern and North Eastern commands. It was also decided that he would take upon himself to try and hold up the English advance to the East and would simultaneously protect the new seat of the government Machadadorp - and would keep open communications with the Portuguese possessions, from which they could still obtain, although with increased difficulty, provisions to feed the armed forces and the local inhabitants. General de la Rey, as the former commandant of the Lichtenburg district had to take charge of the Western Transvaal in order to impede the English from sending small detachments in that direction as far as it was possible. It was assumed that the burghers would be quite willing to return to their camp under these conditions as they would be defending their own farms from the advancing enemy. With the same object in view, and in the same hope, General Grobler was to take charge of the district North of Pretoria, along the railroad to Pietersburg. The South Eastern part of the Transvaal was to remain in charge of Christian Botha, (the brother of the Commandant-General) who was to try to hold up Buller's forces in the event of his advance North across the railway line Pretoria-Komatipoort. It was hoped that such a disposition of forces would be an obstacle to the infiltration of separate English detachment into the interior of the country. Each commando member was supposed to operate within the confines of his own district of enrolment or close to it which had the additional benefit, not only greater enthusiasm in defending one's own home but also of first-hand knowledge of the region in question. At the same time they were recommended not only to defend their positions, but in favourable circumstances to take the initiative and attack enemy detachments of a medium size, provided these had dared to part company with the main forces, or in the cases when they (the Transvalers) had to destroy railway lines, when they were forced to strike at the enemy's rear.

The first English reaction to the early exploits of the Transvalers directed against the destruction of railway lines etc. was to take refuge in repressive administrative measures. Lord Robert's proclamation declared that each case of destruction of railway lines would be punished by the burning of the farm nearest to the incident and that these farms would not only be burned and levelled to the ground but also would have heavy special fines to pay. But the application of these measures did not have the expected results. Instead of stopping guerilla warfare, such as destruction of the permanent way and raids on passing trains, they only irritated the Boers, and at the same time made them realize that they had at last found out the weak spot of the English. Soon after the surrender of Pretoria, General de Wet displayed considerable activity on the territory of the Orange Free State, in the rear of the English, on their, unique line of communication at that period. This caused Lord Roberts to finally order General Buller to begin an offensive along the railway line Ladysmith-Pretoria in order to have the opportunity of using the shorter line from Durban to Volksrust-Pretoria. The Buller offensive, which started first in a Northerly direction, and later moved along the South Eastern railway line, met no serious resistance. But as soon as Buller's troops joined forces with those of Lord Roberts, the last named began to be harassed by guerilla warfare both in the Transvaal as well as in Natal. Thus to begin with the only result of the merger was the increase in the number of men 
who had to get their rations from the Cape Colony along the Bloemfontein-Pretoria's railway line. The traffic along this line had to stop quite often on account of acts of sabotage. The feeding difficulties increased even more because the population of Pretoria, Johannesburg and of the adjoining farms approached the invaders with requests to feed them, as their reserves had been requisitioned by English troops. The English authorities, who had trouble enough to feed their own troops, decided to move Boer families to the Boer camps, hoping in this way to lessen their own supply problem and at the same time to embarrass their enemies by making them responsible for lodging and feeding all the extra number of people. At the same time they began to send all foreigners with their wives and children, which were often very small out of Johannesburg. These families were simply put dumped on to open coal loading trucks along the railway, and in the winter time, with high winds and night frosts, these trucks moved for three days and nights as far as Port Elizabeth or Cape Town prior to their occupants being sent to Europa by sea.

After Buller's troops had approached Pretoria, Lord Roberts undertook another offensive, in an Easterly direction, along the railway line Middelburg-Komatipoort. The Transvaal Government realising fully well the advantages it drew from keeping up communications with Lourenco Marques, wanted to make another attempt to hold up the English offensive by occupying a strong defensive position across the railway line near the Dalmanutha station. The advantage of this position, according to the Transvaal commanders, lay in the fact that it commanded a very wide firing range and made it possible to set guns beyond the line of hills occupied by snipers, heavy siege guns, with a relatively large reserve of shells. However after a strong English bombardment lasting for five days, the Boers retreated into the mountains. During this time a detachment of Johannesburg police proved once more the importance of military training and discipline. Moved to a forward exposed position it was the last to leave having lost more than fifty percent of its component, fighting after the burghers had retreated into the hills.

\section{The Burgher retreat}

The Burgher retreat once begun could not be stopped. The Transvaal commanders should have known from past experience that when the Boers leave a position it is not an easy task to stop them or to introduce order again, that is to say to make them form a military unit again. In the case in point, matters were further complicated by the uneven aspect of the land which continued to the Portuguese border. Meanwhile the commanders placed much hope on the successful Boer operations in this region, especially owing to the fact that the English could get no benefit from their artillery, once they stepped into the narrow winding valleys at the foot of the hills. In cases of attack they either had to do so in the mountains or to undertake encircling movements risking being caught or cut off before the arrival of reinforcements. In view of all this it would have been better to draw the English into the mountains and there try to meet and attack them while their columns were separated rather than occupy a set position at Dalmanutha. Had this been done the English would not have been able to profit from their superiority of numbers or from their artillery. These regions would have been particularly suitable as a fighting arena for guerilla warfare because at that time, that is the second half of August - mountain valleys are already covered with spring grass - excellent fodder for horses.

The English offensive stopped at the Portuguese border, but the Transvalers could not push the English troops back. It had been decided in advance that should the enemy enter into the mountains and occupy the railway lines - all commands should move back and take supplies to the North to the hilly Lydenburg district. This movement was executed so swiftly and successfully that the Boers managed to take not only most of their ammunition with them, but also all their artillery, among it the four siege guns, although one could tell in advance that these were not destined to fire another shot.

But if they had found possible to take away and conceal heavy guns, the same cannot be said of the aged President whose wanderings from place to place appeared very risky and whose capture would have had a very adverse effect on the population of both republics that was still fighting. Because of this the former decision about the President Kruger's departure to Europe - in case of the English occupation of all the line Pretoria-Komatipoort, was applied in practice. The President arrived in Lourenco Marques during the first days of September in order to proceed to Europe. After he left the presidential power passed to Schalk Burger - who had become Vice-President after the death of general Joubert. After the government had moved to the North-Eastern Transvaal, and the English had occupied the railway line, the troops under 
General Louis Botha's command, could, in the same way as other commandos under, de la Rey, Grobler, Christian Botha and others, turn to guerilla warfare. This was made easier because of the good pastures. In actual fact that was the beginning of the development of guerilla warfare which spread in a widening circle. At the same time the Transvaal armed forces grew in numbers. With the arrival of winter, which had coincided with enemy entry on Transvaal soil, many Boers had come down with their families and cattle into the low veld on the Portuguese border and in the North western regions, hoping that military operations would cease by the spring and that they would be able to go back to their farms. With the arrival of spring they were forced by circumstances to leave those parts, on account of terrible fevers and epidemics raging there during that season. This would have deprived them of their only remaining wealth - their cattle. But is was impossible to return to their farms, not so much because their country was under enemy occupation, but because most of their farms had been burnt or destroyed by the English. It is only natural that having nowhere to go, and nothing to defend, the Boers joined others in the Boer camps and thus increased the ranks of the fighters. When they did so the government took upon itself the care of their families, giving them other provisions beside meat, which they still had in abundance.

The fact that guerilla warfare did not develop on the same scale in the Transvaal as it did in the Orange Free State can only be explained by the absence there of men who could be guerilla leaders. If it is difficult in general in any army to produce gifted and outstanding guerilla chiefs so that they remain rare anywhere - how much harder it is for a guerilla chief to distinguish himself in a country where the very notion of guerilla warfare was something strange and where none of the military leaders had received any, not even elementary military training. In these circumstances a guerilla fighter had to be someone quite special - with an original, inborn talent. Judging by everything, a man named Theron, who had displayed extraordinary bravery during the first months of the campaign, and who later joined the forces of de Wet with his commando was such an outstanding person. Having caused not one but several derailments of English troops moving within the Transvaal. Theron most unfortunately lost his life in August.

\section{The outlook of the Burghers wrt War}

So it took a year of campaign to first change the
Boers' outlook on the means of waging war and then secondly to make them act accordingly. If the change of outlook turned out to be the inevitable consequence of events, which proved once and for all the uselessness of the means adopted and at first considered the only possible and infallible ones, their actual application was largely due to the English. Although for a whole century England has had dealings with the Boers, she has, it seems, in the person of her administrators and commanders, failed to understand their character. At any rate the people who were responsible for measures, which, it was hoped would stop the spread of a nation wide war, and to even force the Boers to lay down their arms, had no perception whatsoever of the special distinguishing traits of that people. They did not understand that love of home and of property, of its inviolability - is something of the utmost importance in the eyes of the original inhabitants of the republic. Nor did they understand that many ordinary farmers, i.e. poorly educated Boers, prized the inviolability of their possessions as much - if not more than the independence of their country. By this independence they mean material independence in the sense that they have a guarantee that they themselves and their properties would not be overburdened with heavy taxation. The English also failed to take into account that one of the factors inspiring the continuation of the war was the inborn hostility towards England and the conviction implanted in each Boer, from his earliest childhood onwards of the perfidiousness of the English Government. The measures adopted by the English authorities only encouraged the growth of this feeling, and served as an opportunity to enflame the hatred and the ingrained outlook on England and its administration, further to the advantage of the leaders of both the republics. The repressive measures, such as the burning and destruction of property, as well as forced indemnities in the guise of provisions, and particularly horses, in the case of those farmers, who had remained on their lands in spite of the English approach, did not only scare but exasperated the population to such an extent that, having nothing more to lose, they were quite willing to join in the guerilla warfare, hoping to get some kind of loot from the enemy. The severity of the English towards the Boers merged into cruelty. They would chase Boer families out of their farms put them under armed guard, and keep them on the verge of starvation. All this did not help to decrease the hatred, all the more so as the Boer authorities made a point of publishing such information, giving the names and places in 
their proclamations. Finally the publication by the English authorities of proclamations about the inviolability of property and person to those who returned to their farms and even of the issue of fire arms to them was in complete contradiction with their practice, which was to imprison anyone capable of carrying arms on the slightest pretext. This gave grounds to the governments of the republics to accuse the English authorities of treachery and to persuade the population not to believe their promises. The final result of the devastation of the territories of the republics, particularly of the Orange Free State, was the shifting of guerilla warfare into the confines of the Cape Colony, where relatively small Boer detachments could find means of subsistence without any difficulty.

\section{Characterization of some of the outstanding Boer leaders}

\section{President Paul Kruger}

The personality of the old President of the Transvaal Republic is sufficiently well-known on account of his political activity to describe it in detail. Belonging to that generation, which grew up and was brought up at a time when it was impossible to receive even some kind of elementary education, when the Transvaal could

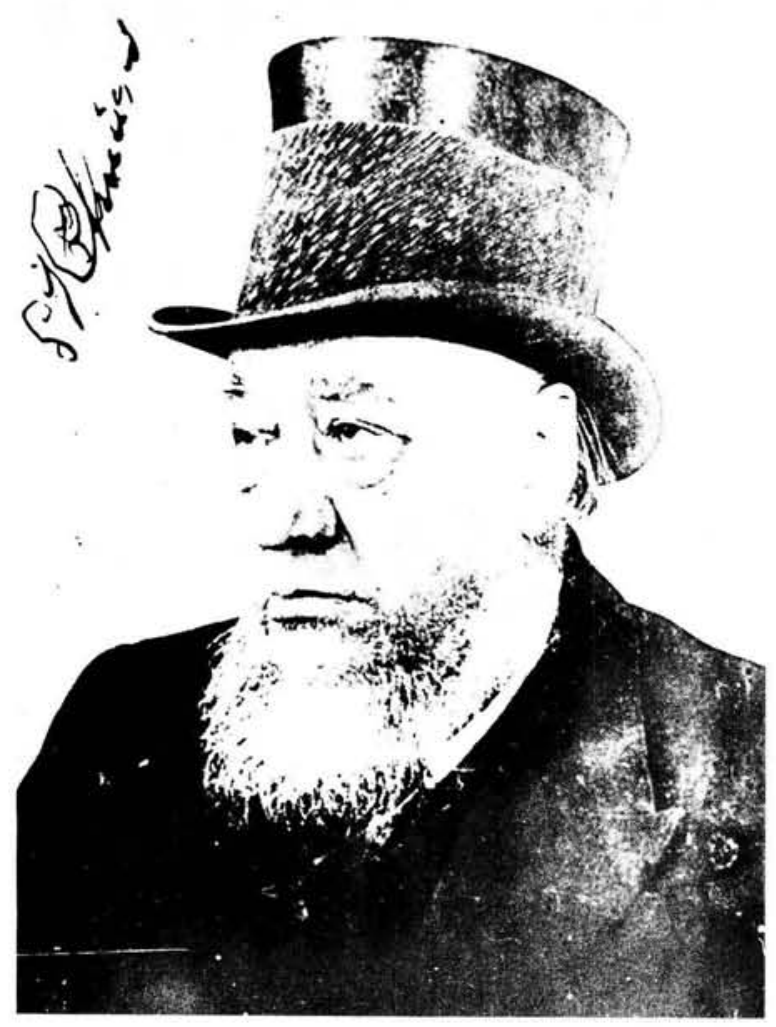

President S. J. P. Kruger in all justice be called a Boer - that is to say a peasant-republic, it is only quite natural that President Kruger's academic training was limited to a knowledge of how to read and write. The only book which disciplined his mind and which was the base of his worldly wisdom was the New and the Old Testament. Thanks to a remarkable natural intelligence, shrewdness and common sense only, was he able to fill up the gaps in, or rather the absence of education. The journey, which he undertook to Europe in the eighties somewhat widened his mental horizon.

The enormous popularity, which Kruger enjoys among the vast majority of the burghers is due to his being recognized as one of the chief leaders of the revolt of $1880-1881$ and to his achievement of securing the final recognition of complete independence of the Republic in 1884. His popularity also rests on the fact that he is considered to be the most vehement and convinced opponent of the peaceful-economic conquest of the country by foreigners, particularly by the English, and the trusted defender of national interests. Besides his natural intelligence he has also extraordinary tenacity and will-power, passive at times, but, especially taking into account his lack of education, he is undoubtedly a most remarkable personality in every way. The distinguishing features of his character are his deep religiousness and his sincere faith in Divine Providence. His basic aim is the preservation of the country and of its wealth for that people which was the first to settle in the present territory of the Transvaal and which grew roots in it at the cost of heavy sacrifices after a bitter struggle with native tribes. He sincerely believes, with the rest of his people, that the gold ore found in the ground is a gift from God - a reward and a consolation for the sufferings of the past. Knowing well, at the same time, that at the present moment the Boers have neither sufficient capital, nor sufficient scientific and technical knowledge by themselves, to exploit the natural riches of the land, without outside help, he is doing his utmost to hold up the tempo of industrial development of the country, so that the young growing and now studying generation of Boers can, in time, take a more active part in the exploitation of these natural riches, which, moreover, are not considered to be inexhaustible.

\section{President of the Orange Free State, Martinus Steyn}

The President of the Orange Free State Martinus Steyn, can be considered as belonging to the new 


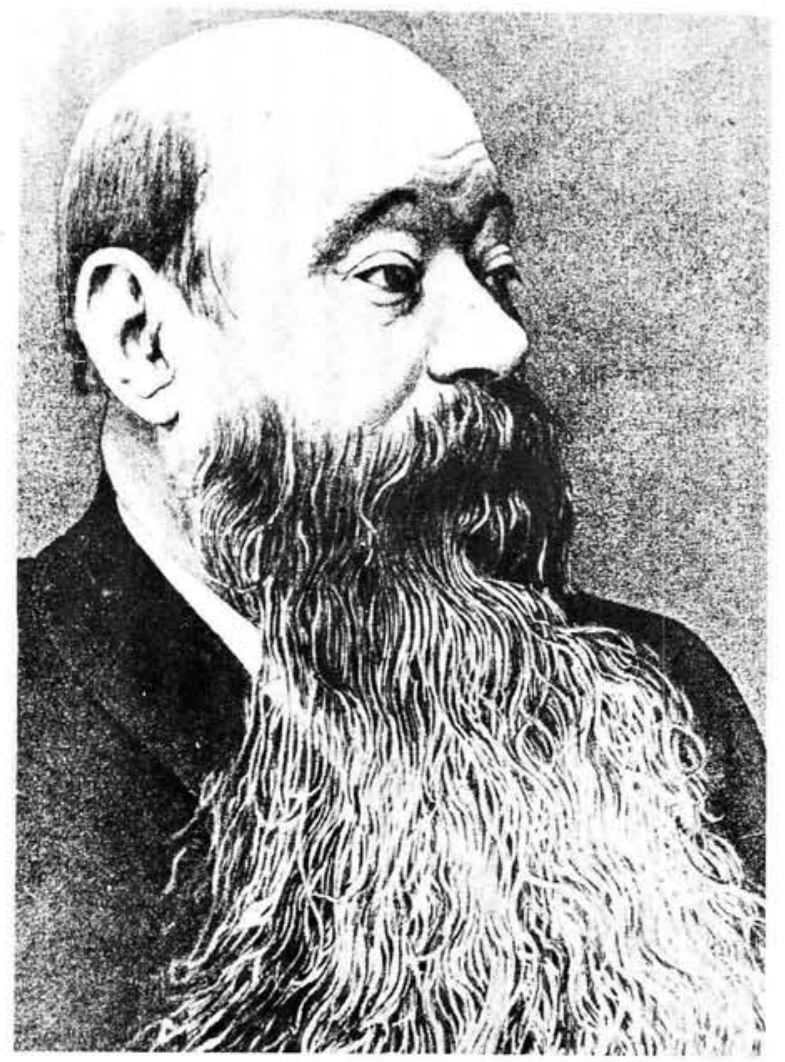

President M. T. Steyn

generation of the South African Republics both because of his age and his education. It is clear that being a gifted administrator, he has also a certain flair for military pursuits. But he has preferred to decline any direct participation in the direction of any military operations, especially from the time when General Christian de Wet's talents were revealed in this sphere. Steyn has an outstanding gift as a public speaker and can stir and captivate his audience. His outlook on life is such that he is not only convinced of the righteousness of the cause, which he is trying to help by every means in his power, but he also does not lose faith in a successful conclusion to the war - and is not dismayed by the great sacrifices which will be expected from the S.A. Republics. Profoundly convinced that the fate of both republics is closely bound together and that the fall of one of them, particularly the stronger one - the Transvaal, under the yoke of a foreign power, would cause the other's downfall, he has always shown himself a staunch supporter of a close alliance between them. For that reason, in spite of the very favourable terms offered to him before the war by the English - (to conclude a separate agreement with the Orange Free State,) he preferred to remain true to the obligations taken upon himself towards the kindred allied republic. Moreover - at a moment of vascillation of the Transvaal government, he was the first to use his influence to keep up its morale and to inspire courage and hope of a better future to it on condition of a struggle to the end. After the English occupation of Kroonstad, which had become the official seat of the government of the Republic, he joined his troops, sharing all the rigours of camp life and dangers with them. With a gun in hand, he set his burghers an example of bravery and cool-headedness in battle. Before President Kruger's departure for overseas, in order to see him personally, he arrived in Nelspruit from the Orange Free State accompanied by his young son, having crossed territory occupied by the English and later rejoined de Wet once more the same way.

\section{Commandant-General Piet Joubert}

The second person of importance in the republic at the beginning of the campaign, and in a sense Kruger's opponent as he was his rival for the presidency, was the Commandant-General and the Vice-President of the Republic, Piet Joubert. He was one of the most important leaders of the, so-called First War for Independence 1880-1881, and one of the chief heroes of the event which is a national glory of the Boers - the battle of

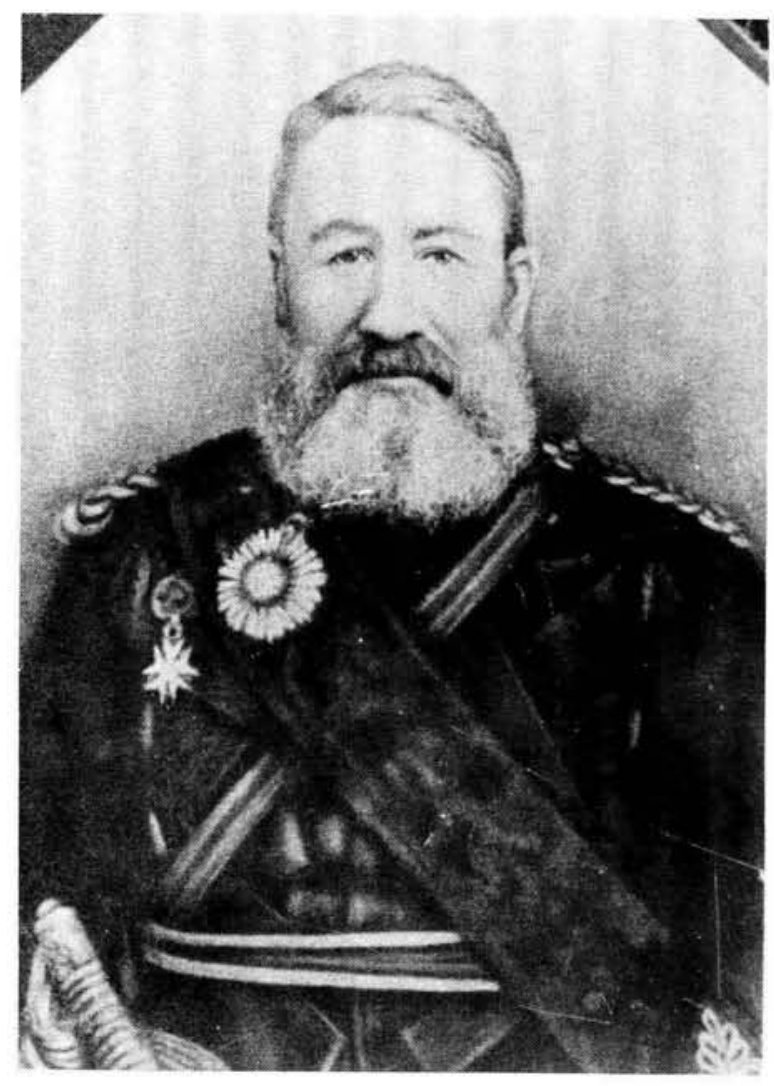

General P. J. Joubert 
Amajuba. He was popular and liked by most of the population, which accounts for his being chosen to hold two positions, which can, but do not have to be united in the same person. However one cannot say that the choice of Joubert as Commandant-General was a good one. He quite frankly admitted himself that he was 'not a good general in war time'. Aware of this and lacking military training, he declined, from the very beginning of the campaign to take charge of military operations both in a general and in any specific way. Remaining almost all the time on the Natal theatre he was not even always aware of what was happening on other fronts. Although entitled by law to make decisions on his own initiative and responsibility, he preferred to act as the chairman of the Krygsraad only. It must be said that thanks to his natural tact and understanding of the characters of his fellow citizens, he directed the Krygsraad in a very capable manner. One of his merits lay in a complete absence of ambition and self-conceit and in his fervent desire to serve the general cause. He was quite sincere when he wrote: "I have never thought about ranks, never considered myself higher than the others, but all of us are equally responsible and duty bound - like myself' and when he declared in the Krygsraad: "I want to be the servant of the

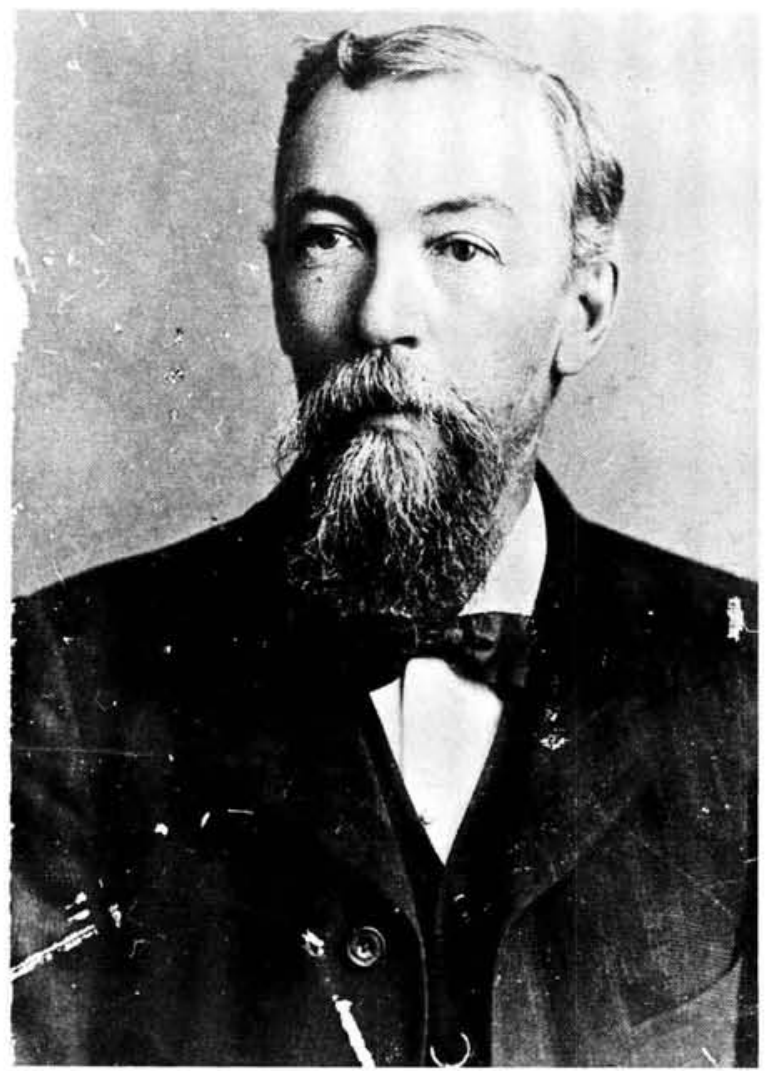

General S. W. Burger least important man, provided he is capable of standing up for the independence of both the republics'. However one must add that his popularity or rather the confidence in him as a military leader - were considerably shaken between the opening of the campaign and the time of his death. His passing did not create a very strong impression and had no influence on the course of military events. While still alive, he had, as a matter of fact passed on the powers vested in him, to his assistant - Louis Botha, even making a statement in the Krygsraad that the latter's orders should be obeyed like his own.

\section{Acting President Schalk Burger}

General Joubert's position as Vice-President was taken over after his death by Schalk Burger, who was appointed by the President, as it was impossible to hold elections. He was chosen because after Wolmarans' departure to Europe he was the only member of the Executive Assembly remaining in the country. As a member of a peace delegation, after the capture of Cronjé, he was the second person of importance, after the President. $\mathrm{He}$ was an unsociable and morose man, somewhat suspected of being prone to innovations, such as showing favourable treatment to foreigners and he was not very popular either among the mass of the population or among the burghers whose commander he was, but who did not have confidence in him. When the English occupied Spionkop, by a surprise attack during the last days of January, he ordered his camps to be packed up and the men to retreat. But he was stopped in time and returned to the front lines, after which he was replaced by someone else and recalled to Pretoria in order to sit in the Executive Assembly in Wolmarans' place. One can definitely state that had it been possible to hold proper elections he would not have been chosen. But when he had been appointed it had not been foreseen that the President would have to leave the country and would pass on the governing of the republic to Burger.

\section{Acting-Commandant-General Louis Botha}

After Joubert's death and in view of the impossibility of electing a Commandant-General in war time (with the President's consent) and as if by choice of the deceased CommandantGeneral, Louis Botha was appointed to this position. Still quite young, Louis Botha is already a representative of the new, young generation. Born in the Northern Natal, he received a good 


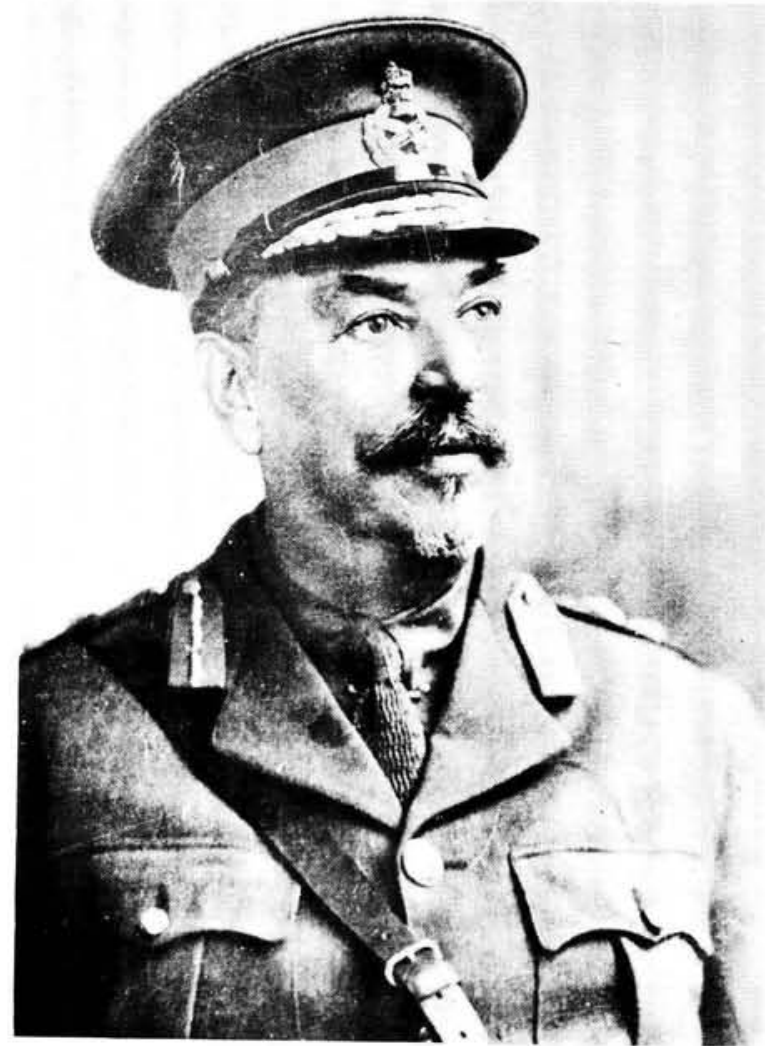

General L. Botha

education in the higher English school in Cape Town and assimilated quite successfully the outer manifestations of English culture. But in his heart he remained the ardent defender of the independence of his country, both political and economic. His closer acquaintance with the English and their culture only strengthened his feeling of dislike for this haughty and selfish nation.

His position as Commander in Chief of the Transvaal forces was far from easy especially to begin with. The reasons for this were that he had not been elected like all other people holding responsible positions in the land, and that many generals older than he, considered that they had greater right than he to command. This situation was somewhat eased by the fact that he enjoyed the confidence of the burghers. This confidence and his popularity grew after the battles of Colenzo and Spionkop, in which the burgher commandos took part under his leadership. Although he alone was not responsible for the turn of events in these engagements, according to the inexplicable mass logic, his very participation in them had an enormous significance, for his reputation as a military leader. Having been well educated, he had received no military training whatsoever and had never prepared himself for such a position. Only certain inborn qualities helped him to carry out all the tasks imposed upon him. These qualities are: perfect self-control and a calm, which never failed him even in the midst of battle, the gift to find his way in any unknown district and a natural tact, which helped him to get on with those around him. Knowing in principle that most of the time the Krygsraad fails to take a satisfactory decision and only hinders the direction of military operations, he still considered it necessary to consult it, partly because of an ingrained habit and on account of most people's confidence in collective decisions, partly because of being aware of his position as a Commandant-General, of not having been elected but appointed by the President who thus set aside men not only older than himself, but who had already won, not only in the present campaign but in former expeditions against native tribes a considerable reputation for themselves. Aware of the fact that a great advantage can be derived from guerilla warfare, especially after the English had occupied Pretoria, he was forced to continue positional tactics in order to prevent the English, for as long as possible, from seizing the new seat of government and in order to preserve contact with the outside world by means of Delagoa Bay. However, it is doubtful, whether he will prove himself to be an outstanding guerilla

\section{General C. R. de Wet}

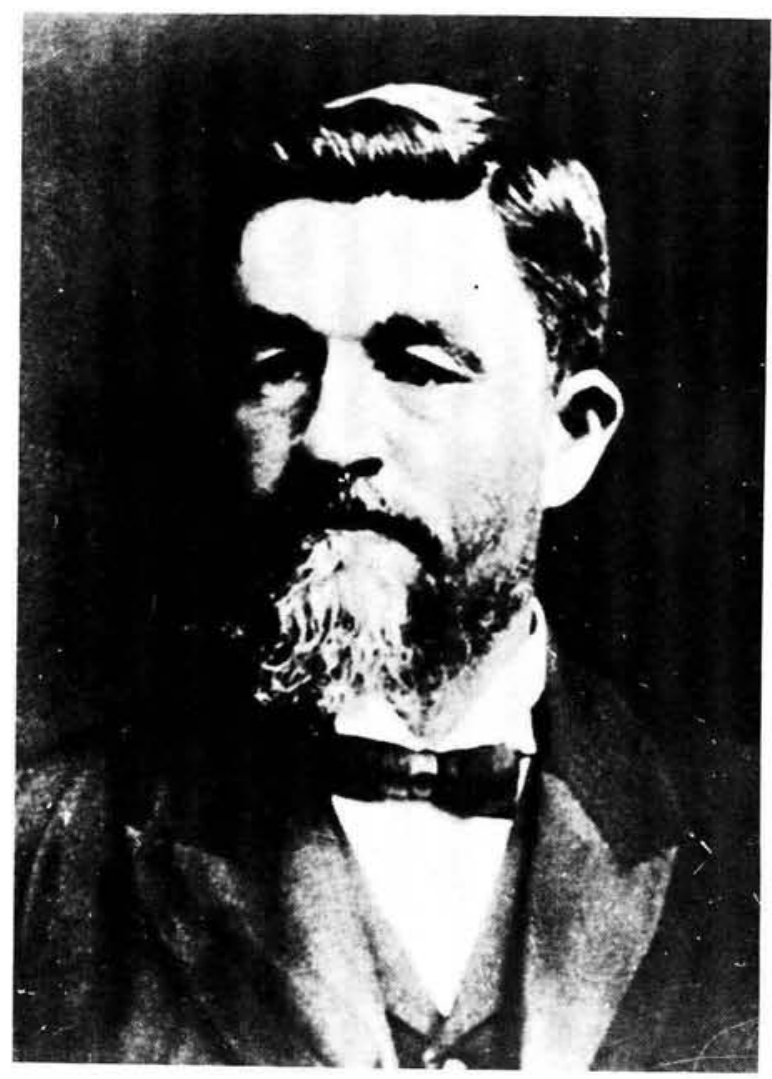


leader or not. One is rather inclined to be of the opinion that when the right time comes, he will render service to his country by conducting the negotiations and obtaining as favourable conditions as possible at the termination of this war.

\section{General Christian de Wet}

It is absolutely beyond doubt that the most outstanding personality brought to the fore by the Anglo-Boer War is that of the Chief Commander of the Orange Free State forces - General Christian de Wet. A middle aged man, he is a fairly well-to-do farmer who has received a rather ordinary education. However even before the war he was so much respected by his fellow citizens that he had been chosen the commandant of his district. Beneath the exterior of a good natured, modest man he conceals an ardent temperament, which reveals itself in extraordinary energy, initiative and presence of mind. Very brave in battle, he ignores dangers in a daring manner, contrary to the Boer custom, which naturally impresses his men. He is often seen along the trench lines or along the crest of the hill riding a white horse, which made him the target of enemy fire. It is not surprising that legends are woven around him like those that surround any national

\section{General J. H. de la Rey}

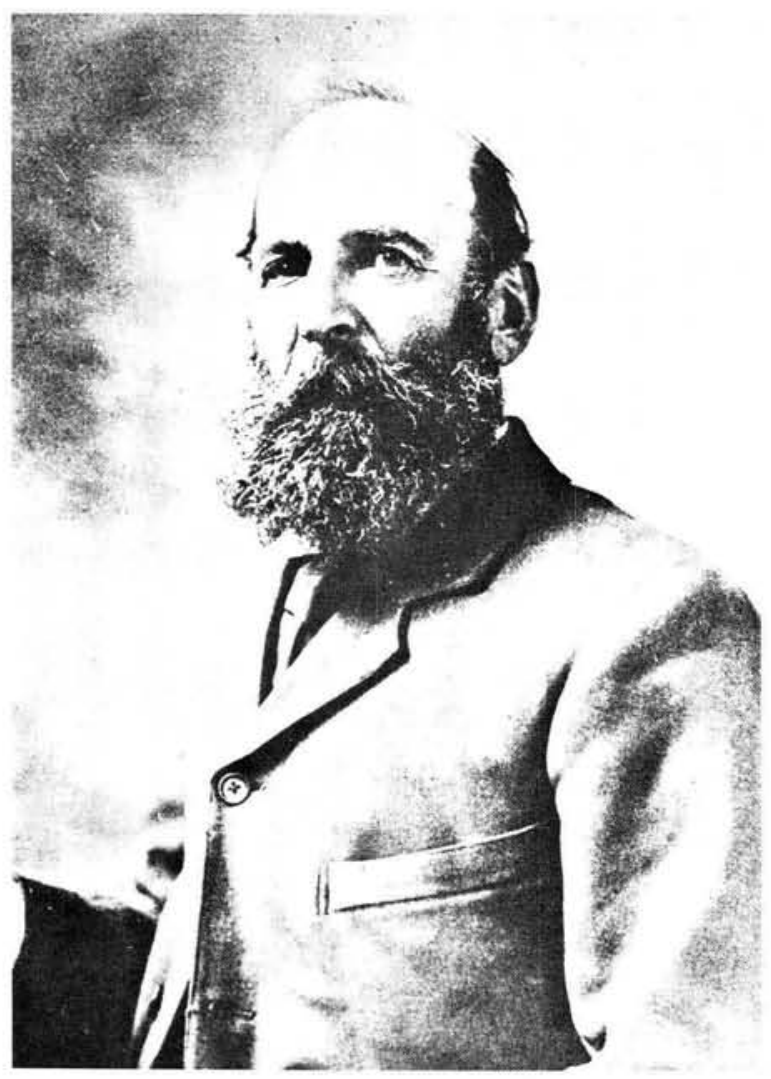

hero. His personality is such that it impresses not only his own people but also the enemy, who consider him to be a real menace. It is said that the English commanders deem it an honour to themselves to have encounters with de Wet even when one of them ends as a failure for them.

The first period of the campaign, during the strictly defensive tactics of the Boers, did not give de Wet the opportunity to display his capabilities. The first action which placed him in the front rank of other Orange Free State Commanders was his capture of the provision transport on the Riet River on February 15 th.

This capture took place in the vicinity of the whole army of Lord Roberts and could have had immense repercussions, had equal activity been displayed by the Boer commandos near Colesberg, in the De Aar direction in the rear of Robert's army. When the English occupied Bloemfontein he set himself as his object to act on the flanks and in the rear of the English, and put his plan into action displaying extraordinary mobility and vigour, which far from weakening becomes more and more intensive with the passage of time.

\section{Assistant Commandant-General de la Rey}

The most deserving of his popularity of the Transvaal generals after General Botha, is General de la Rey - the victor of Magersfontein. At the beginning, after the appointment of General Botha he considered himself to have been bypassed and stood aside from active participation in the Southern theatre, where he had not been entrusted with the general command since most of the troops were composed of Orange Free State burghers. In time he accepted the command round Mafeking, but he arrived on the site almost the day before the attempted storming, the failure of which cannot be blamed on him. Soon after the surrender of Pretoria he received quite an independent allocation to go to his native Lichtenburg, whose commander he had been for a long time, and to organize new commandos there from among those Boers who had gone home. Enjoying great popularity in his own and surrounding districts, he managed to get together several thousand men and to wage a successful guerilla warfare to the north-west of Pretoria in spite of the fact that part of the time he had as his opponent one of the most popular and energetic English generals, if one is to judge by a reputation, Baden-Powell, the 
defender of Mafeking. General de la Rey is a man of about fifty. Being a well-to-do farmer he has received a certain amount of education and gained his military knowledge from experience, having taken part in several expeditions against native tribes. He was among the first to perceive the futility of the positional system unreservedily accepted at the beginning of the war, but while fully aware of the necessity of a more active course of action, considered it wiser to adopt it by degrees, in order to be quite sure of the result and not to compromise this new system by some mishap. One can conjecture that he will become an experienced guerilla fighter, who might not attempt any rash plans, but who will be able to do a great deal of harm to his opponent, with the smallest amount of risk for his own men. $\mathrm{He}$ is a very brave man, and like most Boers very calm and cool-headed.

\section{Theron}

One of the most outstanding and promising Transvalers - on account of his bravery as a guerilla fighter, was a man named Theron - a Johannesburg advocate by profession. Even before the beginning of the war he became known because - he one day entered the offices of an English newspaper, published at the expense of Johannesburg capitalists, and gave the editor a beating since the latter had written an article offensive to the Republic of the Transvaal. It must be admitted that his action was not approved of in Pretoria, but when the campaign started, rather than to join the Johannesburg commando, he called for volunteers to form a special reconnaisance detachment and about fifty brave and keen men answered his call. His detachment served on the Southern theatre during the first period of the campaign. The audacity of Theron and his men who, during their reconnoitring quite often entered into the very heart of English camp positions, has become legendary. Unfortunately all these raids were of little practical use as during that period the Boers were not undertaking any offensive and did not therefore need the information he succeeded in obtaining. After the occupation of Pretoria by the English about a hundred men gathered round him. Realizing that the most fruitful opportunity for guerilla warfare would present itself on the confines of the Orange Free State, he joined the forces of General de Wet. He and his detachment displayed an extraordinary activity during the months of June and July. Several of the derailments, ascribed to de Wet, were actually caused by Theron and his men. During one of these attacks, it was only thanks to chance and a good mount, that Lord Kitchener escaped, and being taken prisoner. There were weeks when Theron and his men had daily encounters with the enemy. At the beginning of August he was mortally wounded after which it seems that his detachment has fallen apart.

\footnotetext{
* For the introduction by Mrs E. Foxcroft and the biographical note, refer to part 1 of the article in Militaria 11/4 of 1981.
} 